\title{
МЕТОДИЧНЕ ЗАБЕЗПЕЧЕННЯ ТА ОСОБЛИВОСТІ ВИКЛАДАННЯ АПТЕЧНОЇ ТЕХНОЛОГІЇ ЛІКІВ В УМОВАХ КРЕДИТНО-МОДУЛЬНОЇ СИСТЕМИ
}

О. М. Барна

ДВНЗ “Тернопільський державний медичний університет імені І. Я. Горбачевського МОЗ України”

\section{METHODOLOGICAL PROVIDING AND PECULIARITIES OF TEACHING OF PHARMACY TECHNOLOGY OF DRUGS IN THE CONDITIONS OF CREDIT-TRANSFER SYSTEM}

\author{
O. M. Barna \\ SHEI "Ternopil State Medical University by I. Ya. Horbachevsky of MPH of Ukraine"
}

\begin{abstract}
У статті наведено окремі аспекти впровадження кредитно-модульної системи у викладання аптечної технології ліків, описано особливості підготовки студентів спеціальності “Фармація”. Визначено основні переваги кредитно-модульної системи організації навчального процесу порівняно з традиційною.
\end{abstract}

The article adduces some aspects of the introduction of the credit-transfer system in teaching the Pharmacy Drug Technology, peculiarities of training of students in specialty "Pharmacy". The main advantages of the credit-transfer system of organization of educational process compared to the traditional were determined.

Вступ. В умовах співпраці України із країнами світу перед системою освіти постають нові завдання та розкриваються нові перспективи. У підготовці майбутніх фахівців акценти зміщуються у бік використання інноваційних освітніх технологій, спрямованих на якісний освітній результат, що дає можливість підготовки висококваліфікованих кадрів, що будуть конкурентоспроможними на ринкупраці, а саме здатні до компетентної, відповідальної та ефективної діяльності за своєю спеціальністю на рівні світових стандартів.

Саме це спричинило інтеграцію України до європейської системи освіти і зумовило необхідність переходу вищої школи до нової кредитно-модульної системи організації процесу навчання й оцінювання знань студентів і збагачення їх інтелектуального та творчого потенціалу [5].

Важливою умовою розв'язання цього завдання $\mathrm{\epsilon}$ необхідність озброєння спеціалістів, яких готує вища школа, глибокими професійними знаннями, науковим світоглядом та вмінням працювати з людьми, ліквідація перепонів для розширення мобільності студентів, викладачів і дослідників. У свою чергу, сучасна інформаційна революція вимагає також і постійного оновлення знань, вміння навчатися протягом усього життя. Для цього слід раціоналізувати організацію всього навчального процесу, удосконалити зміст, форми та методи навчально-пізнавальної діяльності студентів вищих навчальних закладів, що якнайкраще розвивало і формувало б творчі здібності студентів $[1,4]$.

Основна частина. Кредитно-модульна система підготовки фахівців вносить значні зміни в організацію навчання у вищому навчальному закладі. Зокрема, це перенесення ваги на самостійну роботу студентів, в якій значну роль відведено бібліотеці, уведення елементів дистанційного навчання та інформаційних технологій тощо.

Суттєві положення КМС-організації навчального процесу полягають, по-перше, у розділенні навчального матеріалу кожної дисципліни на блоки - залікові модулі, які розглядаються як завершені і відповідним чином задокументовані частини навчальної дисципліни $[1,3]$. Таким чином реалізується одна із суттєвих переваг КМС: “середньому” пересічному студенту набагато легше засвоїти (і скласти) навчальну дисципліну за чітко окресленими частинами - модулями [2].

На кафедрі технологіїліків аптечної технологіїліків за кредитно-модульною системою навчаються студенти III курсу та IV, V курсів заочного відділення фармацевтичного факультету. 
Програма з аптечної технології лікарських засобів для студентів вищих фармацевтичних закладів освіти та фармацевтичних факультетів вищих медичних закладів освіти III-IV рівня акредитації складена для спеціальності “Фармація” відповідно до освітньо-кваліфікаційної характеристики (ОКХ) та освітньо-професійної програми (ОПП), затверджених наказом МОН України від 29.07.04 № 629, та експериментального навчального плану, розробленого на принципах Свропейської кредитно-трансферної системи (ECTS). Навчання за цією спеціальністю здійснюється протягом 5 років.

Програма структурована згідно 3 вимогами “Рекомендацій щодо розроблення навчальних програм навчальних дисциплін” (наказ МО3 України від 12.10.2004 p. № 492) [6].

Аптечна технологія ліків - наука про теоретичні основи та виробничі процеси переробки лікарських засобів у лікарські препарати шляхом надання їм відповідної лікарської форми в умовах аптеки за екстемпоральними, фармакопейними та мануальними прописами. Значення екстемпорального виготовлення ліків не можна недооцінювати. Головними перевагами екстемпорального приготування лікарських препаратів $\epsilon$ : індивідуальний підхід до хворого, те, що ці препарати є свіжовиготовленими, практично не містять консервантів, барвників, та ін. Аптечна технологія ліків базується на теоретичних положеннях фізики, ботаніки, мікробіології, фізичної та колоїдної хімії, гігієни, аналітичної і органічної хіміі, фармакології тощо, та відіграє важливу роль у формуванні світогляду провізорів і в забезпеченні їх спеціальної технологічної підготовки.

Програма дисципліни “Аптечна технологія лікарських засобів” має 3 модулі, модуль перший і другий, у свою чергу, поділяються на 2 змістових модулі.

МОДУЛЬ 1. Загальні питання технологї ліків. Порошки. Рідкі лікарські форми. Під час навчання згідно з планом першого модуля студенти вивчають загальні питання технології ліків, опрацьовують нормативно-технічну документацію, згідно з якою здійснюється екстемпоральне виготовлення лікарських форм в умовах аптеки, та робота аптеки в цілому. Вивчають будову та метрологічні характеристики терезів. Відпрацьовують відважування різних за фізико-хімічних властивостями речовин.

Велика увага приділяється прийому рецепту та перевірці правильності виписування лікарської форми $з$ подальшим приготуванням пропису.

Перший змістовий модуль включає в собі вивчення технології твердих лікарських засобів, а саме по- рошків 3 речовинами, які відрізняються насипною масою, щільністю, кристалічною будовою, а також барвними, важкоподрібнюваними, пахучими речовинами та екстрактами. Особлива увага приділяється виготовленню порошків з сильнодіючими та отруйними речовинами.

Другий змістовий модуль включає технологію рідких лікарських форм, а саме концентрованих розчинів, мікстур, крапель, неводних розчинів (спиртових, гліцеринових, олійних), розчинів високомолекулярних сполук, колоїдних розчинів, суспензій, емульсій, настоїв та відварів.

МОДУЛЬ 2. М'які та асептичні лікарські форми. Утруднені прописи. Фармацевтичні несумісності. В третьому змістовому модулі студенти вивчають технологію м'яких лікарських форм, а саме лініментів, гомогенних і гетерогенних мазей та супозиторій методом викачування та виливання.

Четвертий змістовий модуль включає в себе вивчення лікарських форм, що потребують асептичних умов приготування.

Студенти на заняттях ознайомлюються з санітарним режимом і правилами роботи в асептичних умовах, навчаються готувати розчини для ін'єкцій, суспензії для ін'єкцій, очні лікарські форми, лікарські форми 3 антибіотиками. А також ознайомлюються 3 утрудненими випадками приготування лікарських препаратів, фізичними, хімічними, фармакологічними несумісностями в лікарських та косметичних формax.

МОДУЛЬ 3. Виконання та захист курсової роботи.

Вивчення та засвоєння студентами дисципліни значною мірою залежить від мотиваційного рівня, який формується фаховою орієнтацією та можливістю застосування отриманих знань та навичок у майбутній професійній діяльності. Тому важлива роль у навчальному процесі відводиться підготовці курсової роботи, адже дана робота відображає самостійну роботу студента, показує глибину володіння матеріалом, дає можливість проявити і використати нестандартні рішення при вирішенні певного завдання. Даний вид роботи дозволяє формувати навики логічного мислення, основаного на самостійній роботі.

Метою курсової роботи є закріплення та поглиблення знань, які студенти одержали на лекціях, лабораторних заняттях та під час самостійної роботи. Курсова робота $є$ продовженням вивчення класичного курсу аптечної технології ліків, тому їі виконання надає студентам навички пошуку, аналізу та систематизації наукової інформації. Також студенти ма- 
ють можливість отримати консультацію щодо питань, які виникають при підготовці курсової роботи $[6,7]$.

До кожного практичного заняття на кафедрі наявне методичне забезпечення (українською, російською та англійською мовами) у вигляді календарнотематичних планів практичних занять, тематичного плану для самостійної роботи студентів, методичних розробок на практичні заняття для викладачів та студентів, пакета тестового контролю знань, набору ситуаційних занять, тематичних таблиць, відеоматеріалів та методичних вказівок для самостійної роботи студентів.

На занятті студенти отримують індивідуальні завдання у вигляді рецептурних прописів, згідно з якими вони проводять розрахунки з подальшим виготовленням лікарської форми. Кожен студент забезпечений спеціально обладнаним робочим місцем, що дає можливість повноцінно і якісно виготовити запропоновану лікарську форму. Залежно від вивченого модуля студентів забезпечують необхідними речовинами та обладнанням. Навчальна аудиторія обладнана згідно 3 вимогами нормативно-технічної документації, та мак-

\section{Лiтература}

1. Вища освіта України і Болонський процес / під ред. В. Кременя. - Київ - Тернопіль, 2004. -286 с.

2. Власко М. П. Про переваги модульно-рейтингової технології навчання / М. П. Власко, О. В. Устименко // Педагогіка і психологія. -2004. - № 2 (42). - С. 98-106.

3. Енциклопедія освіти / гол. ред. В. К. Кремень. - К. : Юрінком Інтер, 2008. - 1040 с.

4. Козак Т. М. Організаційно-педагогічні засади впровадження кредитно-модульної системи підготовки фахівців у вищих педагогічних навчальних закладах III-IV рівнів акредитації : автореф. дис. ... канд. пед. наук / Тетяна Михайлів- симально наближена до реальних умов. Дана методика дозволяс максимально підготувати майбутнього фахівця до роботи в аптечних закладах. Ще слід відмітити, що підготовка до практичних заняття передбачає надання консультацій студентам [4].

Для проведення лекційних занять створені мультимедійні презентації, які сприяють всебічному сприйняттюлекційного матеріалуі повнішому його засвоєнню.

Висновок. В умовах кредитно-модульної системи навчання організація педагогічного процесу вимагає різностороннього підходу до проведення практичного заняття. Накопичений нами досвід роботи за кредитно-модульною системою викладання свідчить про позитивні наслідки її впровадження. Зокрема, вона впливає на мотивацію навчання студентів, зацікавленість в отримуваних ними оцінках, що сприяє, у свою чергу, підвищенню їх активності в навчальному процесі, з одного боку, та результативності навчання - 3 іншого. Проте варто дотримуватися компромісу між новітніми технологіями навчання та так званим традиційним підходом на першому етапі впровадження.

на Козак; Житомир. держ. ун-т. ім. I. Франка. - Житомир, 2007. $-189 \mathrm{c}$.

5. Кучерявий О. Г. Модульно-розвивальне навчання у вищій школі: аспекти проектування : монографія / О. Г. Кучерявий. - Донецьк : Вид-во ДонНУ, 2006. - 304 с.

6. Типова робоча програма з аптечної технології ліків / під ред. О. І. Тихонова. - Київ, 2011. -60 с.

7. Товажнянський Л. Л. Болонський процес: цикли, ступені, кредити : монографія / Л. Л. Товажнянський, Є. І. Сокол, Б. В. Клименко. - Харків : НГУ “ХПГ”, 2004. $144 \mathrm{c}$. 